\title{
In the Name of (Un)Sustainability: A Critical Analysis of How Neoliberal Ideology Operates Through Discourses About Sustainable Progress and Equality
}

\author{
Diana Jacobsson
}

Department of Media and Communication Studies, Jönköping University, Jönköping, Sweden, diana.jacobsson@ju.se

\begin{abstract}
This article examines sustainable development discourses while addressing the unsustainable structures within which these discourses take place. The main research question concerns how sustainability is understood in relation to class and capitalism and what ideologies are expressed as neutral in the anodyne context of public information. Critical discourse analysis is applied as a method to examine how sustainable development is shaped through the construction of problems, responsibilities and solutions in a Swedish municipal magazine. The analysis reveals two parallel constructions: hyper-politicised discourses about free enterprise and a trivialisation of discourses about socio-economic challenges. Texts about social care and social responsibility are represented in the form of banal politics, transforming conflict into consensus, while stories about the business sector rely heavily on market rationales stressing the importance of political intervention to increase the attractive power of entrepreneurialism. Taking Critical Theory as its starting point, the analysis discusses the neoliberal paradox, namely that in the neoliberal political regime, despite the rhetoric of individualism and freedom, the role of the state is to support private enterprises. The article argues that the role of communication needs further analytical attention to increase our understanding of how sustainability is shaped and established in mainstream public discourse. It concludes that the specific communication practice examined here promotes neoliberal capitalism by encouraging the continued unsustainable class structuring of our society.
\end{abstract}

Keywords: sustainability, ideology, neoliberalism, media

\section{Introduction}

This article examines sustainable development discourses while addressing the neoliberal structures within which these discourses take place. The concept of sustainability and a striving for sustainable development have become standard in public and political discourse in today's societies worldwide. At the same time social unsustainability, in terms of gaps between rich and poor, is growing. Since the 1990s income inequality has risen more rapidly in Sweden than in any other OECD country (OECD Economic Survey of Sweden 2017). This critical discourse analysis starts from that paradox and focuses on public information in the case of a Swedish municipal magazine with the explicit mission to communicate visions of sustainability to local residents and to endorse sustainable actions. According to Fuchs (2017), questions about capitalism and class are largely neglected when actions supporting increased sustainability are promoted in our neoliberal society. In the specific case of the municipal magazine, sustainability visions and diverse texts about sustainable development are expected to be presented as neutral information. A possible dilemma arising in this kind of communication with a clear sustainability profile characterised by consensual authority concerns ways to discursively approach issues in that sociopolitical context that have a negative impact on sustainability. The purpose of this 
study is to examine how sustainable development discourses are constructed in a context where unsustainability, in terms of socio-economic gaps between different social groups, is increasing. To achieve this, the study aims to establish what discourses are constructed in the municipal magazine, what underlying assumptions about capitalism and class are embedded in the sustainability discourses, and what ideologies are expressed as neutral information. The analysis reveals an interesting paradox, pointing to contradictory understandings of problems, responsibilities and solutions in conjunction with sustainable development, depending on whether it concerns the private or public sector. It is argued here that the magazine constructs two opposing discourses simultaneously: a hyper-politicised discourse revealing a dependency relationship between private enterprises and the political sphere; and a disconnecting discourse where socio-economic challenges are constructed as detached from the political sphere and trivialised in a way that implies they are to be solved through isolated, targeted municipal projects and citizen mobilisation. Put differently, this contributes to the institutionalisation of an unsustainable social, economic, and political design of society.

The following section introduces and contextualises the mission of the examined municipal magazine and problematises the role of public information. This is followed by a section presenting the motivation and contribution of the study. The text then moves on to discussing the previously strong focus on the ecological dimension of sustainability, and ways in which debates about sustainable development could be repoliticised by an increased focus on the social dimension, while also highlighting previous research connected to this study. A section introducing Critical Theory and ideology critique and discussing the core characteristics of neoliberal ideology concludes the introductory, theoretical part of the article. This is followed by a presentation of the specific case, materials and method. The empirical part consists of a thematic presentation of the critical discourse analysis. The final section is a concluding discussion where the most important results are highlighted.

\subsection{Desires and Reality}

The concept of sustainability has been identified as playing an important part in the ongoing depoliticisation of modern society (Raco 2014). With its administrative character, it is invoked not in order to question the main power inequalities of capitalism but rather to prevent the critique of power structures in modern society (Fuchs 2017). On the website of the Swedish municipal magazine Our Gothenburg, chosen here as a case study, it is stated that the goal of the city is to be "sustainable and open to the world" and that the magazine wishes to emphasise "developments within the climate friendly city and make visible how the path to a socially sustainable society leaves its mark on everything that is being done". ${ }^{1}$ The description of social sustainability as a guideline that informs "everything" in the municipality is interesting in that it raises questions about how well this desire corresponds with the actual developments in the city of Gothenburg. The latest equality report, with statistics about the socio-economic situation in the municipality, presents 250 pages of alarming statistics reflecting increasing gaps in income, life expectancy and risk of ending up in poverty between different areas of the city. Since the 1990s, inequality in living conditions has been an ever-growing issue, and the gap in mean income between rich and poor continues to widen. Before 1990 there was a 40 percent difference in disposable income between rich and poor areas. In 2006 this difference had increased dramatically (to 262 percent)

\footnotetext{
${ }^{1}$ https://vartgoteborg.se/ (All text translated by the present author.)
} 
and today the difference in mean income between the richest and poorest areas of the city is 290 percent. The difference in life expectancy between the financially strong areas and the weaker neighbourhoods is 7.5 years for women and 9.1 years for men. More than half of households with children in the poor areas risk ending up in poverty while almost every rich-area household with children has a high economic standard. Segregation, poverty and unemployment in stigmatised neighbourhoods also result in differences in health, school performance, and participation in social and political activities. $^{2}$ The mission of the municipal magazine includes reporting about results within a particular project, Equal City, as one part of the effort to achieve increased social sustainability. This means that various social problems need to be addressed, and such a focus implicitly revolves around questions of class, requiring acknowledgement of capitalism's unequal relations and distribution of resources. It is argued here that the stated desire to let the goal of increased equality permeate everything clashes with an unsustainable reality. It should be noted that those producing the content are not journalists who (at least in theory) are tasked with critically examining the political and economic elite and providing information to stimulate critical debate. The magazine appears similar to a journalistic product, but the articles are written by communicators employed by the municipality and paid from tax revenues, assigned to follow the directives set by the municipality. One of these directives is that politicians are not allowed to contribute to the contents. ${ }^{3}$ This brings us to the challenge posed by the municipal magazine and its mission to emphasise sustainability in an unsustainable context. In short, this means that reporting about increasing unsustainability needs to be discursively shaped into neutral information about 'sustainable developments' in the city without acknowledging that the problems are political outcomes. Based on this it is argued here that the sustainability discourses in the municipal magazine contain an inherent conflict.

\section{What is Wrong with Neutral Information?}

This section presents the specific genre of public information. Public information municipal magazines are part of the Swedish national program Citizen Dialogue, motivated as having the ambition to strengthen local democracy in the 290 municipalities. ${ }^{4}$ This informational role and democratic mission have previously been strongly associated with local journalism informing citizens about the work within local government, providing an arena for debate, and holding politicians and administrative elites accountable for situations and developments in the municipality. New channels of communication emerging in the last decade, such as social media, complement local governments' public communication strategies and provide opportunity to reach citizens more directly (Djerf-Pierre and Pierre 2016). The magazine analysed in this study, however, explicitly states that it is without involvement from local politicians and government.

Nevertheless it has been pointed out that there is a fine line between neutral information and political marketing, and that information provided by public sector organizations inevitably concerns highly-contested political issues or policies (Raftopoulou and Hogg 2010). Given that the intention of public information often is to influence the attitude and behaviour of citizens in relation to politically-defined activities (Collins and Butler 2003), this kind of engagement between government and citizens

\footnotetext{
2 Jämlikhetsrapporten 2017.

3 https://vartgoteborg.se/

${ }^{4}$ Project Citizen Dialogue: Citizen dialogues - 250 examples from Sweden, SKL 2015.
} 
must be seen as essentially political (Ryan 2001). The non-ideological character of sustainability and the way it is highlighted in public information have led to its being identified as a topic that allows for avoiding confrontational class politics, instead emphasising collaboration and consensus (Wilson and Swyngedouw 2014; Raco 2014; Raco, Imrie and Lin 2012). In public information services run by governments or public-sector organisations, the implied role of the initiator is that of an impartial, external party. In a study of social marketing campaigns, Raftopoulou and Hogg (2010) claim, however, that it is inevitable that particular understandings of an issue or decision that are in line with the view of the initiator are advocated. The labelling of public information as neutral is, then, a contradiction in itself. The neutral presentation of choices citizens can make, for example in public or private healthcare and elderly care, implies a view of citizens that transforms them into consumers making rational choices in their own individual best interest (also Redclift and Woodgate 2013). When this kind of information surrounds the processes of important societal developments, it alters the relationship between the state and the citizens, replacing public debate with market rationalities and rendering invisible the question of public goods and unequal power relations (Raftopoulou and Hogg 2010).

\section{The Study of Sustainability Discourses}

The examination of mainstream sustainability discourses is crucial, as communication plays an important role in social systems. It is the key to how we understand complex social issues and how established discourses become collective definitions of reality (Fuchs 2017). Sustainability discourses can guide our decisions and shape our views on what actions to promote sustainability are reasonable, while claiming to be an "objective necessity" and a neutral "distribution of the sensible" (Ranciere 1999, 13). This means that sustainability discourses have the inherent power to be instruments for governing society. Tahvilzadeh et al. (2017) have shown the effects of sustainability discourses in urban politics, how they emerge, acquire structure, and become institutionalised and hegemonic understandings. Their study concludes that, despite inadequate and paradoxical results in terms of both policy objectives and outcome, talking about and aiming for sustainability are still successful practices in the local political context.

The concept of sustainability has been criticised for being a tool contributing to the demise of democratic government and for disguising political responsibility and actions (Raco 2014). One potential risk with this kind of blurred responsibility is that it becomes harder for the ordinary citizen to actively participate in democratic processes in society. When no one is responsible, there is nowhere to turn. Wilson and Swyngedouw (2014) claim that this post-political condition is constructed by specific mechanisms and practices. According to this line of reasoning, sustainability communication, as a practice, can thus play an important part in constituting the post-political and reducing politics to a kind of consensual management of economic necessity. However, the idea behind the Swedish Citizens Dialogue Project, of which the municipal magazines are an important part, is presented as the opposite: as being put forward to strengthen democracy and empower the citizens via information, transparency and openness. ${ }^{5}$

In line with the work of critical scholars who argue that sustainability is in fact highly ideological (e.g. Luke 2005; Harlow et al. 2011; Redclift and Woodgate 2013; Fuchs 2017 ) it is relevant to examine what ideologies are expressed and presented as neutral information in the name of sustainability. The current study springs from the tradition

\footnotetext{
${ }^{5}$ Project Citizen Dialogue: Citizen dialogues - 250 examples from Sweden, SKL, 2015.
} 
of critical discourse analysis and Critical Theory, centred around the idea that social power structures are reflected in and reproduced through the dialectic relationship between discourse and society; i.e., that discourse both shapes and is shaped by society (Fairclough 2014). A critical discourse analysis can show how ideologies are constructed and promoted to create a certain understanding of a social event, so that it appears natural and commonsensical while alternative viewpoints and interpretations of situations and relations are downplayed or concealed (Machin and Mayr 2012). This study contributes knowledge about the reproduction and negotiation of power and ideology through discourse. It highlights the naturalisation of ideology, making (de)politicising processes visible and showing what ideological claims are made in the name of sustainability.

\subsection{Facing Nature We are One}

The concept of sustainability and the actual definition of what sustainable development means have been and still are in the hands (and reflect the interests) of Western international organisations with close ties to the international political and economic establishment (Worster 1993; Fuchs 2017). Sustainable development was first presented as an idea almost four decades ago in a report from the International Union for the Conservation of Nature (1980), and a few years later the United Nations (UN) declared it a global goal in order to mitigate climate change (WCED 1987). Today the idea of sustainable development has a central position in local, national and international discourses about the planning, decisions and policies that supposedly guide our present and future societies worldwide. Sachs (1993) claims that the reason for the central position of sustainable development and the consensus surrounding it is that it offers a link between ecological and economic interests. This makes it possible for contradictions between capitalism and ecology to be obscured. Sustainability, as a beacon, seems to bridge traditional political divides and erase the lines of conflict between opposing social classes. The social neutrality of ecological sustainable development can function as a means of conflict avoidance for the establishment, as it offers arguments about the conflict being between generations instead of among them (Baeten 2000). The previously strong focus on ecological and economic sustainability has been criticised for mostly resulting in a green rhetoric which in the end is synonymous with business as usual (Luke 2005). According to Baeten (2000) the movement towards increased sustainability is highly conservative; it does not (intend to) challenge capitalism and consumerism, but instead celebrates it, as long as it calls itself green. In a critical study of how certain groups in society are disempowered and neglected in city planning, Baeten (2000) emphasises how sustainability, like all general interest ideologies, serves the purpose of masking particular interests. A focus on ecological sustainability offers, according to his study, the possibility to pretend that everyone, irrespective of social class, employment and income, is "in it together", united in striving to hand over a sustainable planet to future generations. A common assumption underlying ecological sustainable development is that we all share this planet and therefore we will all be equally affected if we move in an unsustainable direction. However, Fuchs $(2017,445)$ argues that "in class societies, those who are rich in terms of the amounts of the wealth, income and power they control are likely to be less affected by unsustainability", concluding that resource inequality is the definition of unsustainable development, and attention therefore needs to be given to the fact that unsustainability is class-structured. Because the previously narrow focus of the sustainability concept on the environment has broadened to become more 
multidimensional and also to include social sustainability, the topic of equality should now be placed at the heart of the concept (Fuchs 2017).

\subsection{Social Sustainability Discourses and Unsustainable Societies}

There is an increased focus in academic research as well as political and public debate today on how to organise society in a more fair and just, and also socially sustainable, way. This trend however runs parallel with the rise of neoliberal capitalism, which has brought an increase of inequality. In Sweden, capital gains have boosted top incomes at the same time as benefits have increased more slowly than wages. Income inequality has increased more rapidly than in any other OECD country. Since the 1990s the difference in real disposable income between the top and the bottom has increased more than 50 percent (OECD Economic Survey of Sweden 2017). Social sustainability emphasises the importance of social homogeneity, for example in terms of equitable incomes. With reference to this, Sweden seems to be heading in an unsustainable direction. Fuchs (2017) discusses the multidimensional (social, environmental and economic) understanding of sustainability, which underlies the 17 goals put forward in the 2030 Agenda for Sustainable Development (United Nations 2015), and points to the lack of mention of class and capitalism as issues that can negatively influence sustainability. This tendency within both academic and political/public discourse to only take advantage of the positive connotations of sustainability without critically engaging with its social dimensions has been acknowledged in previous work. It has been argued that the (over)use of the concept of sustainability today merely serves as a disguise, as it has become synonymous with the promotion of economic growth (Tahvilzadeh et al. 2017; Redclift and Woodgate 2013; Cox and Béland 2013). Another study in the same critical vein comes from Raco, Imrie and Lin (2012) who claim that sustainability is utilised to deal with conflicts and collective issues in a depoliticised consensus-driven manner. According to Harlow et al. (2011) sustainability needs to be seen as an ideology that, by neglecting the impact of society's power structures, implicitly justifies the unequal distribution of wealth in capitalistic class societies. The ongoing broadening of the concept and practice of sustainable development to increasingly embrace the social dimension could mean a greater challenge in preserving the status quo. The concept of social sustainability focuses on equality, and topics connected to allocation of resources therefore need to be addressed. The idea of social equality contains a more visible social-political conflict line that should make issues related to equality harder to frame as neutral. The possibility to obscure class stratification and the capitalist system that comes from focusing solely on ecological sustainability may be reduced by an emphasis on social sustainability, as questions of equality are more visibly related to the concept of class and the uneven distribution of resources in neoliberal capitalism. This somewhat naive assumption is however opposed by a number of studies, for example Cuthill (2009) and Davidson (2014), who argue that the emphasis on social sustainability has not yet affected the umbrella under which different perspectives can be sheltered.

In summary, the critique of sustainability both as a scholarly concept and as a public and political ideal revolves around how it is or can be used to promote forms of development that in fact are unsustainable from a class and equality perspective, while neglecting and marginalising these elements. This connects to the broader critique of consensus-based politics as being an illusion (e.g. Mouffe 2005; Ranciere 2006; Swyngedouw 2007; 2009; Wilson and Swyngedouw 2014; Raco 2014) and calls for empirical studies springing from Critical Theory to explore how various understandings and discursive constructions of sustainability relate to questions of ideology, class and 
inequality. This article explores these questions from the perspective of the field of critical media and communication studies. Previous studies have examined Swedish national sustainability discourses (e.g. Hilding-Rydevik et al. 2011; Bradley 2009) and international ones (e.g. Raco 2014; Redclift and Woodgate 2013; Raco, Imrie and Lin 2012; Vallance et al. 2011; Redclift 2005; Luke 2005). The function and effects of specifically local urban sustainability discourses have been examined in various studies that conclude that the discourses serve as door openers for development based on a market-oriented rationale placing economic growth foremost in importance (Tahvilzadeh et al. 2017; Gressgård 2015; Jonas 2015; Krueger and Savage 2007; Jonas and Ward 2007; Brenner 2009). Knowledge about how underlying assumptions and understandings of capitalism and class operate when sustainable development is discursively engineered on a local level is, however, still needed. The current study focuses specifically on how sustainability is understood in relation to class and capitalism and what ideological standpoint is expressed in the name of sustainability.

\section{Critical Theory, Ideology Critique and Sustainability}

This analysis springs from Critical Theory, which was first developed by the Frankfurt School (see Horkheimer and Adorno 2002/1944) and paved the way for Marxistinspired scholars to emphasise how societal power structures and concepts like ideology and hegemony are of central importance in media and communication studies. Critical Theory views the neoliberal structures of society as allowing certain social groups to accumulate economic, political and cultural capital while excluding others. It argues that when the class interests of elites become the leading principles of social systems, societies are heading in an unsustainable direction (Fuchs 2017). A critical analysis of sustainability discourses can reveal the doings of neoliberalism how power, exploitation and domination work through communication practices and ideologies and how unsustainability can be justified and rationalised through a process of naturalisation, where the influence of capitalism and class is made invisible. The processes whereby political responsibility decreases, citizens are encouraged to individually choose welfare products in an extended market, and market logic is seen as the voice of reason are often referred to as depoliticisation, individualisation and marketisation respectively, and have been identified as both interrelated core characteristics and outcomes of neoliberal ideology (Bourdieu and Wacquant 2001; Harvey 2005; 2010; Hay 2007; Lazzarato 2009; Amable 2010; Giroux 2015). The successful reshaping of responsibilities in the neoliberal regime, and shifts in what parts of an issue are given priority, are important as they affect the common-sense understandings of different political decisions and social conditions. This depoliticised naturalisation process relates to the ideological character of sustainability discourses in that it allows the catch-all positive connotations of the sustainability concept to be included and emphasised by groups representing totally opposing political interests (Fuchs 2017). In the end, sustainability can mean anything, and the possibility to discuss it in terms of conflict and structural inequalities decreases. As pointed out by O'Connor $(1994,152)$, "who in his or her right mind would be against 'sustainability'?". Harvey $(2005 ; 2010)$ argues that neoliberalism should be understood foremost as a deliberate project for the restoration of class. The structure of class is defined by conflicts of interests, as capitalists' profit is dependent on the surplus value that can be produced. This makes exploitation the core of the social relation between capital and labour (Marx 1996/1867; Wright 2005). In a neoliberal context, this relationship is obscured. Established common-sense discourses instead emphasise consensus and collaboration and promote the ideas of individual freedom and flexibility (Nafstad et al. 
2007; Lazzarato 2009). Harvey (2005) stresses that we need to understand neoliberalism as something more than (just) a free market regime eager to cut loose from the state. Despite the rhetoric about individual freedom being hindered by a strong state, the state is needed by the 'free' market. Harvey calls this inconsistent relationship the "neoliberal paradox" and points to how the state bears the role of ensuring the neoliberal political goal: to protect and support the financial system and free enterprise.

\section{Case, Material and Method}

Gothenburg is a suitable case for a study examining sustainability discourses. The City of Gothenburg is the second largest city in Sweden, with half a million inhabitants and another million in the neighbouring areas. The municipality is deeply engaged with sustainability discourse, which is said to dominate the city's policy ambitions. Municipalities play an important role in all Western European societies, especially in the Nordic countries, and together with the state they are responsible for deciding, implementing, and maintaining measures to promote environmental, economic and social sustainable development (SOU 2007, 10). All 290 Swedish municipalities have for more than a decade been incorporated in a larger national plan, the Citizen Dialogue Project, which aims to develop, coordinate and strengthen local and municipal activities ${ }^{6}$, with municipal magazines as one important part (SKL 2015). Gothenburg presents itself with the slogan "Sustainable city - open to the world". The municipal magazine Our Gothenburg distributes three to six issues per year free of charge to every household in the municipality. It received an award in 2017 for its "high quality" content in the category of public sector information. ${ }^{7}$ The empirical material for this study consists of the eight issues distributed during 2016 and 2017, four from each year. Each issue has 24 pages with articles about different local actors, events, plans and projects, emphasising sustainable development. Commercial advertising is not allowed. Communicators employed by the municipality and paid from tax revenues are tasked with producing the magazine to communicate sustainability visions, projects and activities to the citizens in the form of neutral information. The stated mission of the magazine is to communicate sustainability visions and actions and to endorse sustainable solutions within the everyday life of the local residents. ${ }^{8}$ The choice of this magazine as empirical material is based on its explicit aim to provide neutral public information with an emphasis on sustainable development. The neutrality claim is valuable from a critical discourse perspective as texts claiming to be neutral inevitably reveal common-sense assumptions (Wodak and Meyer 2009), in this case taken-forgranted understandings of capitalism and class. The magazine is also an interesting site of struggle. It seems reasonable to assume that local politicians and officials, as well as various local corporations and organisations, are strongly motivated to attempt to influence the content of the magazine, as it implicitly has a strong marketing function. It is also tangential to criticism concerning communicators taking over duties previously connected to (local) journalism: providing transparency about the local political decision procedure, holding politicians accountable, and informing citizens about political decisions that have been taken by the city council, while providing an arena for critical debate on this.

\footnotetext{
${ }^{6}$ Project Citizen Dialogue: Citizen dialogues - 250 examples from Sweden, SKL, 2015.

${ }^{7}$ https://vartgoteborg.se/

8 https://vartgoteborg.se/
} 


\subsection{Critical Discourse Analysis}

Critical discourse analysis (CDA) is built on the assumption that power relations are discursive - that power is practiced and transmitted through discourse. The purpose of this study is to examine how sustainable development discourses are constructed in a context where unsustainability in terms of gaps between different social groups is increasing. To achieve this, the study aims to establish what discourses are constructed in the municipal magazine and what underlying assumptions about class and capitalism can be detected. Particular attention will be given to how social sustainability projects, public community services, and local private businesses are represented in recurring parts of the content presented under the headings Strategic Business Dialogue and Entrepreneurialism, Equal City and Social Care. This choice has been made in order to examine how the social, economic and political design of the local community is understood. CDA has been chosen as a method to identify the assumptions and ideas that underpin the process of construction and representation in the municipal magazine texts, with particular emphasis on their ideological functions, i.e., ways in which the texts serve to create and sustain taken-for-granted viewpoints in relation to sustainability. The choice of method is based on CDA's being a form of discourse analysis that focuses in particular on the relationships between discourse, power and ideology (see Wodak and Meyer 2009; Fairclough 2014). The main research question concerns how sustainability is understood in relation to class and capitalism and how this is discursively shaped in terms of problems, responsibilities and solutions in the municipal magazine. The analysis draws on critical discourse analytical tools, as outlined by Machin and Mayr (2012). It focuses on the recontextualisation of sustainable development through the micro-process of events; how simplified meaning is created; and what is obscured and made into common sense through the ways salience/suppression (what is being foregrounded and backgrounded), presuppositions (concepts and worldviews that are taken for granted) and nominalisation (how agency is concealed to simplify complex processes) are made use of in the text.

\section{Hyper-Politicisation and Trivialisation}

CDA often focuses on typical discourse fragments, that is, the different topics each text deals with (Wodak and Meyer 2009). The current analysis identifies two main discourse topics and reveals two parallel constructions: hyper-politicised discourses about free enterprise and a trivialisation of discourses about socio-economic challenges. The first section below shows how the presupposition that the growth of businesses is important in the efforts to achieve sustainability is salient in the municipal magazine. The stories about the business sector rely heavily on market rationales stressing the importance of political intervention to increase the attractive power of entrepreneurialism. The second section shows how texts about social care and social responsibility are represented in the form of banal politics, transforming conflict into consensus. Inequality is not understood in the magazine as a political question, but as a nature-given 'reality'. Underlying socio-economic factors and the class dimension of these questions are never explicitly raised as problems that can explain the situation. 


\subsection{Neoliberal Capitalism - Never Mentioned, Constantly Present}

It is worth noting that politicians are not allowed to contribute to the magazine's content, as this could give the impression of bias and political marketing. ${ }^{9}$ This concern does not, however, extend to the Confederation of Swedish Enterprise (Svenskt Näringsliv), Sweden's largest and most influential business federation, which presents itself as follows on its website: "In a nation with a long tradition of strong unions and a government committed to an egalitarian society, the role of the Confederation is critical in protecting, supporting and promoting the interests of businesses as well as in creating broad popular support for the value and importance of enterprise. A key Confederation position is that businesses are crucial for the existence of a prosperous society". ${ }^{10}$ The current analysis shows how this line of reasoning is echoed in the municipal magazine. Under the recurring headings Strategic Business Dialogue and Entrepreneurialism, sustainable development is repeatedly linked with the importance of having a thriving business sector. It is presented to the readers in various stories about and interviews with business leaders and corporate representatives from local companies. A four-page spread, in Issue 4, 2017, focuses on the positive developments in the car industry, more specifically the Gothenburg-based company Volvo Cars. The introductory article has the headline We are in the midst of a fantastic time period placed next to a picture of a man in a suit, presented as the CEO of Business Region Gothenburg. The CEO is also quoted in the running text: For the businesses that are such an important part of Gothenburg to succeed we need to be able to attract employees with new competence as well as other businesses. The four other articles in the spread are interviews with different people connected with Volvo Cars, who are represented in one article each, where they get to express the importance of Volvo Cars for a sustainable city and a sustainable car industry. The articles associate the growth of business with sustainability, which is visible already in the headlines: It is attractive to work here (interview with the head of technical solutions); It revolves around sustainability (interview with the production manager); Gothenburg is a hub for the automotive industry (interview with the HR-boss); and We will manage fossil free transports before 2025 (interview with the senior adviser). How the need to be attractive as a company can be helped is revealed in the concluding sentence and quotation of the last article, where the senior advisor explains the importance of an extended infrastructure:

Since the new year the Volvo group's main office is in Lundby, close to the core business. During the coming ten years, the area will be developed and preferably be integrated with Lindholmen. But for that to become a reality a connection is needed over the railway and the freeway. - It would mean a lot for the west part of Hisingen to be a part of the development at the riverbank (Our Gothenburg 2017).

This content is presented under the heading Strategic Business Dialogue - a sustainable city - open to the world and is an example of how sustainability is depicted as related to private enterprise. The presupposition that the growth of businesses is important in the efforts to achieve sustainability is salient throughout this spread. The implicit message is that businesses should therefore be provided with whatever they need. The text mentions that the area will be developed, a nominalisation which

${ }^{9}$ https://vartgoteborg.se/om-vart-goteborg/

${ }^{10}$ https://www.svensktnaringsliv.se/english/about-us 563030.html 
conceals the complex ongoing and contested process of city planning in this specific area (see Brorström 2015; Holgersson et al. 2010). The implied problem in the articles, contents that also could serve as advertisements for the car company, is the obstacle of not being 'attractive' enough to expand at the desired rate. The common sense constructed in the texts is that city districts should be developed in the interest of private enterprises due to their importance for sustainable development. The text prefaces the explanation of what is needed with "But for that to become a reality [...]", which is a presupposition that makes the desire and the solution to one of the implied problems seem like a reasonable request.

In Issue 4, 2016, the same discursive strategy is chosen, and the same presupposition becomes visible when stressing the importance of business. The editorial written by the municipal chief executive has the headline: A good life is closely related to being able to find a job and manage on your own. This sentence is repeated in the running text and expanded with a more explicit explanation of how to achieve a good life: "For that to be a reality it is crucial that Gothenburg has successful businesses". This presupposition, expressed in the editorial, is visible throughout the special section labelled Entrepreneurialism. Five articles are devoted to establishing the societal importance of 'simplifying' the conditions for doing business and making big corporations feel welcomed in the municipality. The articles emphasise reductions in bureaucracy and regulations as key to making the municipality attractive to corporations. This goal is already put forward on the front cover of this issue: The investment will make Gothenburg the best city for entrepreneurs. Inside the magazine, in the introductory article to the four pages about the business world, where the writers of the magazine explain the problem to the readers, the message is repeated: "That businesses and the municipality work well together is important for the city's climate". This "collaboration" is then explained with a quote from the "head of establishments" at Business Region Gothenburg: "We should view the entrepreneurs who are contacting the municipality as clients. And we should measure client satisfaction and strive for it to be as high as possible".

One of these entrepreneurs/clients is the owner of a chain of restaurants. In an article with the headline It's important to hit the gas the exhortation for political measures benefiting private businesses is put forward:

The response you get from the municipal administrators is important, but the most important thing for the business climate, according to Lorenzo Baniassadi, is that politicians on the very highest level in the municipality decide what they want with the city: - The most important thing for both small and large businesses is for Gothenburg to hit the gas and show a desire to be in the front line. Businesses want to be where things are happening and evolving, and so you have to invest in order not to fall behind (Our Gothenburg 2016).

The problem is constructed in terms of companies having to deal with, and being constrained by, too many complicated rules, and the solution is to reduce these regulations and make investments in favour of business. The discursive construction of the problem and solution makes the question of responsibility obvious: the market representatives hold politicians responsible and expect political intervention. The fourpage section could be read as an open letter to politicians. First, it establishes the important role businesses play for a sustainable society, and then it quotes voices saying that the business climate needs to be simplified, supported and given priority. The presupposition that a healthy business climate is the key to a prosperous society 
is established in the editorial and implied throughout the four-page section in this issue. The incitement to emphasise the importance of deregulation is declared openly. Different measurements and rankings of the business climate in the municipality, one done by the Confederation of Swedish Enterprise and presenting a negative trend, is mentioned as a driving force in the introductory article: "It was against this background that the city's efforts to simplify the conditions of doing business took off". The transparency about being encouraged by the interests of this influential Confederation implies that it is not seen as political bias to promote the confederation's interests in the guise of public information. The present article argues that the articles presented under the headings Strategic Business Dialogue and Entrepreneurialism connect to hyper-politicised discourses drawing on the political idea of the free market being a guarantor for a sustainable welfare society. The discursive shaping of private enterprises as crucial for society is made salient, which promotes the idea that the city needs to be 'attractive' to these enterprises; that is, organised to their benefit.

\subsection{The Trivialisation of Socio-Economic Challenges}

The magazine does not exclusively focus on business issues and market solutions; it also contains recurring sections with articles about the efforts to increase social sustainability in the municipality, as this allegedly "leaves its mark on everything that is being done". 11 The discursive shaping of the theme of social responsibility is not, however, built on the political idea of raising taxes or redistributing wealth. In terms of neutrality, it could perhaps be expected that this political idea would be put forward under the heading Equal City. The right-wing/liberal view of how society should be structured would then be represented in a single recurring business section of the magazine, and the more left-wing perspective in another. This part of the analysis focuses on the articles presented under the headings Equal City and Social Care, to show how the problems, responsibilities and solutions in the social sector are discursively constructed in relation to social sustainability.

The task of reporting about the municipal project Equal City makes articles touching on social inequality a frequent feature of the magazine. There is, however, a noticeable difference in terms of salience and suppression, insofar as the causes behind inequality are neglected in comparison to the causes behind perceived problems in relation to the free market and business sector, which are made explicit and presented as common sense. The articles about the campaign for a more equal city start with the solution and point to an understanding of social problems as a natural condition that can be eased or cured by isolated targeted efforts. One of the projects that are highlighted in Issue 4, 2017 aims to increase the reading of books in the so-called "vulnerable areas" of the city. This project is presented in an article with the headline Early reading will create an equal city. The text focuses on how librarians make home visits to families with a newborn child in these areas of the city. "Book Start is a project with the goal of making children come in contact with books early. The IbrahimMahmoud family in Lövgärdet is one of the families that have received a visit - and today books are a natural part of everyday life for little Adam". One of the pictures shows the mother, Jamila, sitting and reading to her son, and the other shows the two of them opening the door to three librarians coming with books. The pedagogical text stresses the importance of books "as a ticket to the world of knowledge" and is supported by quotes from the mother: "He played a lot with toys before. But after Book

${ }^{11}$ https://vartgoteborg.se/ 
Start visited us I have learned that it is good to start to turn pages in books, so now I try to do that as often as possible".

This article is an example of how social equality is shaped discursively in the magazine. Stories about how projects are launched to increase reading, prevent children and teenagers in "vulnerable areas" from missing school, or provide a place to live for immigrants or homeless people all follow the same structure: a trivialisation of socio-economic problems. The focus is on solving some of the symptoms of these problems without any mention or definition of the underlying causes of the problem. Equality as a concept is used throughout the issues examined under the heading Equal Gothenburg, but it is never explained or discussed in terms of systemic and structural factors.

In Issue 4, 2017, an article called $A$ project that engages the citizens makes reference to the results and statistics about the socio-economic situation in the municipality presented in the Equality report (2017):

It has been three years since the work with Equal Gothenburg started - and in a new report the first results are made visible. The results point in several directions simultaneously. For example, the difference in income between high and low wage earners has increased, but there is no result showing differences in citizens' perceptions of their own health and life expectancy. On the contrary, some improvements are noticeable in school results in the city; for example, more pupils in eastern Gothenburg are leaving school with better grades.

In this recontextualisation of the outcomes and perceptions of this social sustainability project, some discursive choices and underlying assumptions become clear. The positive is made salient and the negative is suppressed. When the text mentions the increasing gaps between rich and poor, it does so in half a sentence and then moves on to the results about perceived health and life expectancy. The actual "Equality report" (2017) to which the article refers does reveal class-related differences in how citizens perceive their own health and quality of life, but there are no large differences over time. In the example above, we can see how this is presented in a way that can be interpreted to mean that there are no differences in terms of class. Another way to put it could have been to explain that the gap between the rich and the poor in that specific aspect has not grown at the same rate as income inequality. The Equality report also shows a segregated school situation and decreased social mobility. Presenting this as a positive fact reveals the conscious discursive construction of inequality as something that can be solved through targeted efforts and isolated projects; the magazine constantly presents solutions in the form of different success stories about school attendance increasing in certain areas and individuals getting a better life as a result of a specific project.

Moving on, the text quotes a "developer" of the project Equal Gothenburg talking about one specific school and a positive trend there: "Viewing it at the school level we can see for example a clear improvement at the 'Rya school' on the west side of Hisingen". The article continues by highlighting another part of the Equality report: "Another clear conclusion in the new report is that these questions engage citizens more than was expected". The article ends with a quote from the same project developer: "We can observe a mobilization never before seen, where more people are involved and participating in reducing these differences than we ever thought possible. This shows that there is a huge amount of dedication and commitment to these questions". 
What the developer is referring to when saying that citizens are actively working to reduce inequality remains a rather open question. Their dedication strengthens the positive connotations, but the text does not explain in what way the commitment is or can be channelled. Citizens mobilising for increased equality can mean charity work rather than political engagement. Compared to the hyper-political discourses about the role and rights of private enterprises in society, the articles about social equality construct what may be labelled banal and privatised politics. While the causes of problems connected to running businesses are made visible (too much bureaucracy and regulation, a lack of political will, and insufficient investment measures to benefit businesses, etc.), social problems connected to an unequal distribution of resources and to differences in living conditions are presented in terms of solutions where capitalism and class are not mentioned. This means that separate, shallow solutions to symptoms of the capitalist system and class society are being put forward as a way of working for social sustainability.

The debate in Sweden about the ongoing privatisation of functions and institutions that previously were the domain of the public sector has a clear political conflict line. Sweden has been a laboratory for right-wing and liberal radicalism over the past 15 years. The establishment of for-profit independent schools and privatisation of large parts of the health services are an outcome of a firm neoliberal ideology and the political decisions taken by a coalition of liberals and conservatives. In the municipal magazine, the heading Social Care (a sub-category of Equal City) introduces various project for the socially sustainable city. Issue 2, 2017 has a two-page spread about private elderly care in which the ongoing privatisation is presented without any sign of its being a controversial question.

One article has the headline Freedom of choice in home services, and the preamble introduces the topic:

Having the same people come to help out at home. And preferably with better cleaning up of cupboards. When the seniors at the meeting spot discuss home care, they find there is room for improvements. Next year they will be free to choose between the home care provided by Gothenburg City, that is, the public provider, or a private service (Our Gothenburg 2017).

The text does not provide any background or explanation regarding how this has happened. Nominalisation, the concealing of agents and simplification of complex processes, is activated here when privatisation is presented as something neutral that basically just amounts to an extra choice being made possible. The underlying conflict is suppressed and what is made salient is the positive side of being able to choose which service you prefer. This becomes visible in the mention of "extra services" in the example below. The "extra cost" is not problematised or presented as something that in the end means different levels of home care for the elderly with capital and for those without:

Gothenburg City places the same demands on the private providers as on the public ones. The private ones will probably be able to offer extra services, such as snow shoveling or extra things that need doing inside, at an extra cost. - One thing that doesn't work that well with the public home care is they are not allowed to do cleaning high up on cupboards and such things. I would really like to get help with that, Rolf says (Our Gothenburg 2017). 
A quote from another of the seniors is also used to point out what is missing in the less flexible service from the public provider. The article continues by introducing the 90year-old senior citizen Alva:

Alva is well aware of the change that is going on. - It is about getting all the information before you make a choice. It sounds really good to be free to choose, because as things are now, I am not completely satisfied with how it works. If the private alternative means that I could get the same people to come to my home every day, I would really like to choose that.

The article ends by pushing for the possibility to choose private health care: "It is supposed to be easy and comfortable to make one's choice".

The presupposition of the text is that the privatisation is something that has brought about a positive change within elderly care. The problem that is made visible in the text concerns the public provider being unable to perform in a satisfactory way. Any discussion of possible reasons for this (budget limitations and a drained public welfare sector, for example) is absent in the text. These discursive choices in terms of salience and suppression construct private home care as a solution to the problem, at least for those willing and able to take on an "extra cost", without acknowledging the potential class dimension of such a construct. The unanimous quoted voices and the proprivatisation perspectives constructed in the article show how ideological interests can operate in language.

\section{Concluding Remarks}

Why should we care about how a municipal magazine constructs sustainability discourses? It is argued here that the present analysis provides examples of how mainstream common-sense discourses are constructed in accordance with the system of neoliberal capitalism - discourses that reproduce and promote a neoliberal understanding of society. The fact that the examined communication practice is part of a national project, Citizen Dialogue, represented as aiming to increase democracy and enhance citizens' knowledge of, as well as interest and participation in, societal processes, makes it relevant to examine. The ease with which core principles of market capitalism are put forward in the form of public information should not pass unnoticed. The strength of critical discourse analysis is that it exposes how the discourses are constructed. A study focused solely on categorising and counting what topics and actors are presented could give the impression of a balanced and neutral content, because attention is divided quite equally between private enterprises and social projects. It could then have been argued that the unsustainable effects of class society in fact are acknowledged and represented through the focus on social sustainability presented under the heading of Equal City.

However, the key to understanding how neoliberal ideology operates in the texts lies in analysing how problems, responsibilities and solutions are constructed. The current analysis reveals different discursive constructions and assumptions about political responsibility: while the political sphere is asked to fulfil the expectations of private enterprises, the role of political responsibility in conjunction with socioeconomic inequalities is obscured. The problem for private enterprise is constructed as politicians not doing enough to support the interests of the business sector, and the solution is presented in terms of more pro-business investments and fewer rules and regulations. Inequality, on the other hand, is not understood in the magazine as a political question, but as a nature-given 'reality' that mobilises citizens and motivates 
projects in the work for social sustainability, such as handing out a free book to families in "vulnerable areas". Underlying socio-economic factors and the class dimension of these questions are never explicitly raised as problems that can explain the situation. There are no suggestions about real interventions that could alter the conditions, or any critical examination of the effects of current policies and city planning on social mobility and access. Perhaps this is not to be expected in neutral public information. It is therefore worth noting how highly political standpoints regarding private health care and business (de)regulation can be presented as neutral information. The editorial page of the magazine pushes for the importance of market capitalism, actually describing it as a prerequisite for a sustainable society.

The analysis reveals the "neoliberal paradox" pointed out by Harvey (2005): how neoliberal society, despite the rhetoric of individualism and freedom, is organised with the aim of securing neoliberal political goals and ensuring the protection and support of free enterprise. It further reveals how a communication practice nominally in the service of supplying information to the public constructs seemingly harmless discourses about social sustainability that bear the most typical features of neoliberalism: its emphasis on the individual and on economic framings of what otherwise could be seen as social and political questions (Giroux 2015; Amable 2010; Lazzarato 2009; Hay 2007; Harvey 2005; 2010; Bourdieu and Wacquant 2001). In short, the analysis exposes opposing discourses: the problem-oriented, hyperpoliticised market discourse and the depoliticised, trivial discourse about social issues which focuses merely on solutions. Capitalism is not viewed as an issue that has a negative influence on sustainability. Class is implicitly present as a problematic issue, but the explicit focus lies on individuals, on people living in "vulnerable areas" who are in need of targeted solutions. In this context the concept of sustainability paves the way for discourses promoting market rationales while obscuring the structural inequalities of the unsustainable capitalist class society, and makes it possible to distribute neoliberal ideology in the guise of public information. The trivialisation of politics, for example as constructed in superficial stories about cleaning high cupboards, promotes such things as private elderly care as a buffet of opportunities and obscures the political context and implications. As noted by Swyngedouw (2009), the concept of sustainable development represents an impossible construct driven by "non-ideological", pragmatic, win-win planning and actions. It is argued here that the parallel existence of growing inequalities in Swedish society and the establishment of compact neoliberal discourses as neutral common sense within a national project promoted as a tool for the vitalisation of democracy exposes a troublesome discord. It shows the need for critical research on what is being said in the name of sustainability, for continued debate about the role of communication, and for counter-discourses and suggestions about how society should be organised to be truly sustainable.

\section{References}

Amable, Bruno. 2010. Morals and Politics in the Ideology of Neo-Liberalism. Socioeconomic Review 9 (1): 3-30.

Baeten, Guy. 2000. The Tragedy of the Highway: Empowerment, Disempowerment and the Politics of Sustainability Discourses and Practices. European Planning Studies 8 (1): 6986.

Béal, Vincent. 2012. Urban Governance, Sustainability and Environmental Movements: PostDemocracy in French and British Cities. European Urban and Regional Studies 19 (4): 404-419. 
Bradley, Karin. 2009. Just Environments: Politicising Sustainable Urban Development. Stockholm: Kungliga Tekniska högskolan.

Brannen, Julia and Ann Nilsen. 2005. Individualization, Choice and Structure: A Discussion of Current Trends in Sociological Analysis. The Sociological Review 53 (3): 412-428.

Brenner, Neil. 2009. New State Spaces: Urban Governance and the Rescaling of Statehood. Oxford: Oxford University Press.

Brorström, Sara. 2015. Strategizing Sustainability: the Case of River City, Gothenburg. Cities 42 (4): 25-30.

Bourdieu, Pierre and Loic Wacquant. 2001. NeoLiberalSpeak: Notes on the New Planetary Vulgate. Radical Philosophy 105 (1): 2-5.

Collins, Neil and Patrick Butler. 2003. When Marketing Models Clash with Democracy. Journal of Public Affairs 3 (1): 52-62.

Cox, Robert Henry and Daniel Béland. 2013. Valence, Policy Ideas, and the Rise of Sustainability. Governance 26 (2): 307-328.

Cuthill, Michael. 2009. Strengthening the Social in Sustainable Development: Developing a Conceptual Framework for social sustainability in a rapid urban growth region in Australia. Sustainable Development 18 (6): 362-373.

Davidson, Kathryn. 2014. A Typology to Categorize the Ideologies of Actors in the Sustainable Development Debate. Sustainable Development 22 (1): 1-14.

Djerf-Pierre, Monica and Jon Pierre. 2016. Mediatised Local Government: Social Media Activity and Media Strategies among Local Government Officials 1989-2010. Policy \& Politics 44 (1): 59-77.

Fairclough, Norman. 2014. Language and Power. New York: Routledge.

Fuchs, Christian. 2017. Critical Social Theory and Sustainable Development: The Role of Class, Capitalism and Domination in a Dialectical Analysis of Un/Sustainability. Sustainable Development 25 (5): 443-458.

Giroux, Henry. 2015. Against the Terror of Neoliberalism. Politics Beyond the Age of Greed. Boulder, CO: Paradigm.

Gressgård, Randi. 2015. The Power of (Re)Attachment in Urban Strategy: Interrogating the Framing of Social Sustainability in Malmö. Environment and Planning A: Economy and Space 47 (1): 108-120.

Harlow, John, Aaron Golub and Braden Allenby. 2011. A Review of Utopian Themes in Sustainable Development Discourse. Sustainable Development 21 (4): 270-280.

Harvey, David. 2010. The Enigma of Capital and the Crises of Capitalism. London: Profile Books.

Harvey, David. 2005. A Brief History of Neoliberalism. Oxford: Oxford University Press.

Hay, Colin. 2007. Why We Hate Politics. Cambridge: Polity Press.

Hilding-Rydevik, Tuija, Maria Håkansson and Karolina Isaksson. 2011. The Swedish Discourse on Sustainable Regional Development: Consolidating the Post-Political Condition. International Planning Studies 16 (2): 169-187.

Holgersson, Helena, Catharina Thörn, Håkan Thörn and Mattias Wahlström. 2010. (Re)searching Gothenburg: Essays on a Changing City. Göteborg: Glänta produktion.

Horkheimer, Max and Theodor W. Adorno. 2002/1944. Dialectic of Enlightenment. Stanford: Stanford University Press.

International Union for the Conservation of Nature and Natural Resources.1980. World Conservation Strategy. Living Resource Conservation for Sustainable Development. Accessed December 20, 2018. https://portals.iucn.org/library/efiles/documents/wcs004.pdf

Jonas, Andrew E.G. 2015. Beyond the Urban 'Sustainability Fix': Looking for New Spaces and Discourses of Sustainability in the City. In The Politics of the Urban Sustainability Concept, edited by David Wilson, 117-135. Champaign, IL: Common Ground Publishing. 
Jonas, Andrew E.G. and Kevin Ward. 2007. Introduction to a Debate on City-Regions: New Geographies of Governance, Democracy and Social Reproduction. International Journal of Urban and Regional Research 31 (1): 169-178.

Jämlikhetsrapporten. 2017. Skillnader i Livsvillkor i Göteborg. Göteborg: Social Resursförvaltning.

Krueger, Rob and Lydia Savage. 2007. City-Regions and Social Reproduction: A 'Place' for Sustainable Development? International Journal of Urban and Regional Research 31 (1): 215-223.

Lazzarato, Maurizio. 2009. Neoliberalism in Action: Inequality, Insecurity and the Reconstitution of the Social. Theory, Culture \& Society 29 (109): 109-133.

Luke, Timothy. 2005. Neither Sustainable nor Development: Reconsidering Sustainability in Development. Sustainable Development 13 (4): 228-238.

Marx, Karl. 1996/1867. Capital, Volume 1. New York: Lawrence \& Wishart.

Machin, David and Andrea Mayr. 2012. How to do Critical Discourse Analysis. London: Sage.

Meyer, Michael. 2009. Between Theory, Method, and Politics: Positioning of the Approaches to CDA. In Methods of Critical Discourse Analysis, edited by Ruth Wodak and Michael Meyer, 14-32. London: Sage.

Mouffe, Chantal. 2005. On the Political. London: Routledge.

Nafstad, Hilde Eileen, Rolv Mikkel Blakar, Erik Carlquist, Joshua Marvle Phelps and Kim Rand-Hendriksen. 2007. Ideology and Power: The Influence of Current Neo-Liberalism in Society. Journal of Community and Applied Social Psychology 17 (4): 313-327.

O'Connor, Martin. 1994. Is Sustainable Capitalism Possible? In Is Capitalism Sustainable?, edited by Martin O'Connor, 152-175. New York: Guilford.

OECD Economics Department. 2017. Economic Survey of Sweden. Growing more equal. Accessed December 9, 2018. http://www.oecd.org/sweden/economic-survey-sweden.htm

Our Gothenburg [Vårt Göteborg]. 2016-7. Municipal magazine series. Accessed December 18, 2018. https://vartgoteborg.se/las magasinet vart goteborg/

Raco, Mike. 2014. The Post-Politics of Sustainability Planning: Privatisation and the Demise of Democratic Government. In The Post-Political and its Discontents: Spaces of Depoliticisation, Spectres of Radical Politics, edited by Japhy Wilson and Erik Swyngedouw, 25-47. Edinburgh: Edinburgh University Press.

Raco, Mike, Rob Imrie and Wen-I Lin. 2012. Community Governance, Critical Cosmopolitanism and Urban Change: Observations from Taipei, Taiwan. International Journal of Urban and Regional Research 35 (2): 274-294.

Raftopoulou, Effi and Margaret K. Hogg. 2010. The Political Role of Government-Sponsored Social Marketing Campaigns. European Journal of Marketing 44 (7/8): 1206-1227.

Ranciere, Jaques. 2006. Hatred of Democracy. London: Verso.

Ranciere, Jaques. 1999. Disagreement: Politics and Philosophy. Minneapolis: University of Minnesota Press.

Redclift, Michael. 2005. Sustainable Development (1987-2005): an Oxymoron Comes of Age. Sustainable Development 13 (4): 212-227.

Redclift, Michael and Graham Woodgate. 2013. Sustainable Development and Nature: the Social and the Material. Sustainable Development 21 (2): 92-100.

Ryan, Neal. 2001. Reconstructing Citizens as Consumers: Implications for New Modes of Governance. Australian Journal of Public Administration 60 (3): 104-109.

Sachs, Wolfgang. 1993. Global Ecology. London: Zed Books.

SKL. 2015. Medborgardialoger. 250 exempel från Sverige. Accessed December 20, 2018. https://webbutik.skl.se/bilder/artiklar/pdf/7585-253-9.pdf

SOU [Statens Offentliga Utredningar]. 2007. Hållbar Samhällsorganisation med Utvecklingskraft. Stockholm: Edita Sverige AB. 
Swyngedouw, Erik. 2009. The Antinomies of the Postpolitical City: In Search of a Democratic Politics of Environmental Production. International Journal of Urban and Regional Research 33 (3): 601-620.

Swyngedouw, Erik. 2007. Impossible Sustainability and the Post-Political Condition. In The Sustainable Development Paradox: Urban Political Economy in the United States and Europe, edited by Rob Krueger and David Gibbs, 13-40. London: Guilford Press.

Tahvilzadeh, Nazem, Stig Montin and Mikael Cullberg. 2017. Functions of Sustainability: Exploring What Urban Sustainability Policy Discourse 'Does' in the Gothenburg Metropolitan Area. Local Environment 22 (1): 66-85.

United Nations. 2015. Transforming Our World: the 2030 Agenda for Sustainable Development. Accessed December 9, 2018. https://sustainabledevelopment.un.org/content/documents/21252030\%20Agenda\%20for\% 20Sustainable\%20Development\%20web.pdf

Vallance, Suzanne, Harvey C. Perkins and Jennifer Dixon. 2011. What is Social Sustainability? A Clarification of Concepts. Geoforum 42 (3): 342-348.

Wilson, Japhy and Erik Swyngedouw. 2014. The Post-Political and its Discontents. Spaces of Depoliticisation, Spectres of Radical Politics. Edinburgh: Edinburgh University Press.

Wodak, Ruth and Michael Meyer. 2009. Critical Discourse Analysis: History, Agenda, Theory and Methodology. In Methods of Critical Discourse Analysis, edited by Ruth Wodak and Michael Meyer, 1-33. London: Sage.

Worster, Donald. 1993. The Wealth of Nature: Environmental History and the Ecological Imagination. New York: Oxford University Press.

World Commission on Environment and Development. 1987. Our Common Future. Accessed December 20, 2018. http://www.un-documents.net/our-common-future.pdf

Wright, Erik Olin. 2000. Class Counts: Comparative Studies in Class Analysis. Cambridge: Cambridge University Press [digital reprint].

\section{About the Author}

Diana Jacobsson

Diana Jacobsson is a Senior Lecturer in Media and Communication Studies at Jönköping University where she teaches Critical Media Theory and Sustainable Communication. She holds a PhD in Journalism, Media and Communication from Gothenburg University. Her main research fields are Critical Discourse Analysis of the neoliberalisation of society and studies of class and inequality. Examples of publications are Dismantling Discourses: Compassion, Coping and Consumption in the Representation of the Working Class in Critical Discourse Studies (2016) and Business Elite Competition or a Common Concern, Journalistic representations of industrial crises in Sweden in Journalism Studies (2016). 